\title{
ANALYSIS OF AERONAUTICAL INFORMATION POTENTIAL INCOMPATIBILITY - CASE STUDY
}

\section{ANALIZA POTENCJALNEJ NIEZGODNOŚCI INFORMACJI LOTNICZEJ - STUDIUM PRZYPADKU}

\author{
Ewa Dudek, Michał Kozłowski
}

Politechnika Warszawska, Wydział Transportu

\begin{abstract}
This article is a continuation of the authors' study on the ways to ensure the quality and safety of aeronautical data and information. In its content the Integrated Aeronautical Information Package was presented and its fundamental part AIP Poland was described. In addition, the docking guidance system A-VDGS, being an example of implementation of telematics system in air transport, was discussed as well as its requirements and schematic representation were attached. In the following part of the publication an analysis of AIP Poland in terms of the mentioned aircrafts' docking systems was performed and a discrepancy between the requirements published in ICAO Annex 14 and published information for aerodrome EPWA was noticed. The indicated case of published incompatibility confirms the necessity to develop and implement a complex method of aeronautical data and information quality assurance at all stages of aeronautical data and information chain, which will be the subject of authors' further study.
\end{abstract}

Keywords: aeronautical data and information quality, AIP Poland, A-VDGS system

Streszczenie: Artykut stanowi kontynuację prac Autorów nad zagadnieniem sposobu zapewnienia jakości $i$ bezpieczeństwa danych i informacji lotniczych. $W$ jego treści przedstawiono Zintegrowany Pakiet Informacji Lotniczych oraz szczególowo opisano jego podstawowa część, czyli AIP Polska. Ponadto omówiono system dokowania A-VDGS, będacy przyktadem zastosowania systemu telematyki $w$ transporcie lotniczym. Przedstawiono wymagania z nim zwiazane oraz rysunki pogladowe. $W$ dalszej części publikacji dokonano analizy AIP Polska w zakresie wspomnianych systemów dokowania statków powietrznych, stwierdzając rozbieżność między wymaganiami opublikowanymi w Załaczniku 14 ICAO $i$ opublikowanymi informacjami dla lotniska EPWA. Wskazany przypadek opublikowanej niezgodności potwierdza konieczność opracowania $i$ wdrożenia kompleksowej metody zapewnienia jakości danych i informacji lotniczych na wszystkich etapach łańcucha danych lotniczych, co będzie przedmiotem dalszych prac Autorów.

Stowa kluczowe: jakość danych i informacji lotniczych, AIP Polska, system A-VDGS 


\section{ANALYSIS OF AERONAUTICAL INFORMATION POTENTIAL INCOMPATIBILITY - CASE STUDY}

\section{Introduction}

Air transport is a domain that develops very dynamically. The resulting therefrom action, aimed at increasing airspace capacity, however cannot take place at the expense of air traffic's safety, but only with the improvement of information transmission systems. In Air Traffic Management (ATM) the growing dependence on telematics systems (particularly those related to data sharing and transmission of information) can be observed. Requirements, procedures and regulations being in force in the civil aviation, discussed in more details in other Authors' works [1, 2, 4], aim at ensuring the adequate level of flight operations' safety. As the efficiency and effectiveness of air transport operation is strongly dependent on the supply of proper quality information in previous works (e. g. [2, 3]) the Authors proposed a comprehensive and systematic approach to quality assurance at all stages of the aeronautical data and information chain. They also drew attention to the fact that despite that unintentional human errors are the statistically dominant cause of aviation safety events, in the statistics of those events we also deal with cases of proper systems' or human behaviour (e.g.: of a pilot or air traffic controller) based on data vitiated by an error that occurred and has not been identified and corrected at any stage of those data creation, collection or processing [5]. One should also be aware that the data error can occur at any stage of the aeronautical data and aeronautical information supply chain [2] also in transfer, publications and interpretation phases, while its cause, source, place, and manner of materialization can be extremely different. What's more, aeronautical data error's appearance may not be (and most unfortunately is not) identified at the time (or place) of its occurrence.

This article is a continuation of the authors' study on the ways to ensure the quality and safety of aeronautical data and information in the entire process (considered as the supply chain) of those data and information creation, collection, processing and publication. In its content the Integrated Aeronautical Information Package was presented and its fundamental part - the Aeronautical Information Publication (AIP Poland), being one of the basic aviation documents was described, emphasizing that the information contained therein, as a basis for planning and safe conduct of the flight, must always be up to date and ready to use. In addition, the Advanced Video Docking Guidance System - A-VDGS, being an example of implementation of telematics system in air transport, was broadly discussed. Its requirements and schematic representation were presented, bearing in mind that the reliability of the system's operation and correctness of the information at its display have a direct impact on the safety of taxiing operation and aircraft's guidance to the particular aircraft's stand. A case study carried out in this paper illustrates the complexity of the analysed issue to ensure the quality of aeronautical information. 


\section{Integrated Aeronautical Information Package}

Aeronautical data and information are published to ensure safe and regular air navigation, in accordance with the requirements of ICAO Annex 15 [11], which specifies the information to be shared, and their related quality requirements. From the point of view of the issues addressed in this publication, it is necessary to discuss wider the Integrated Aeronautical Information Package (Figure 1), provided by the Aeronautical Information Service of the Polish Air Navigation Services Agency. Since the package is one of the basic aeronautical documents forming the base for the planning and safe conduct of the flight, the information contained herein must always be correct, up to date and ready to use.

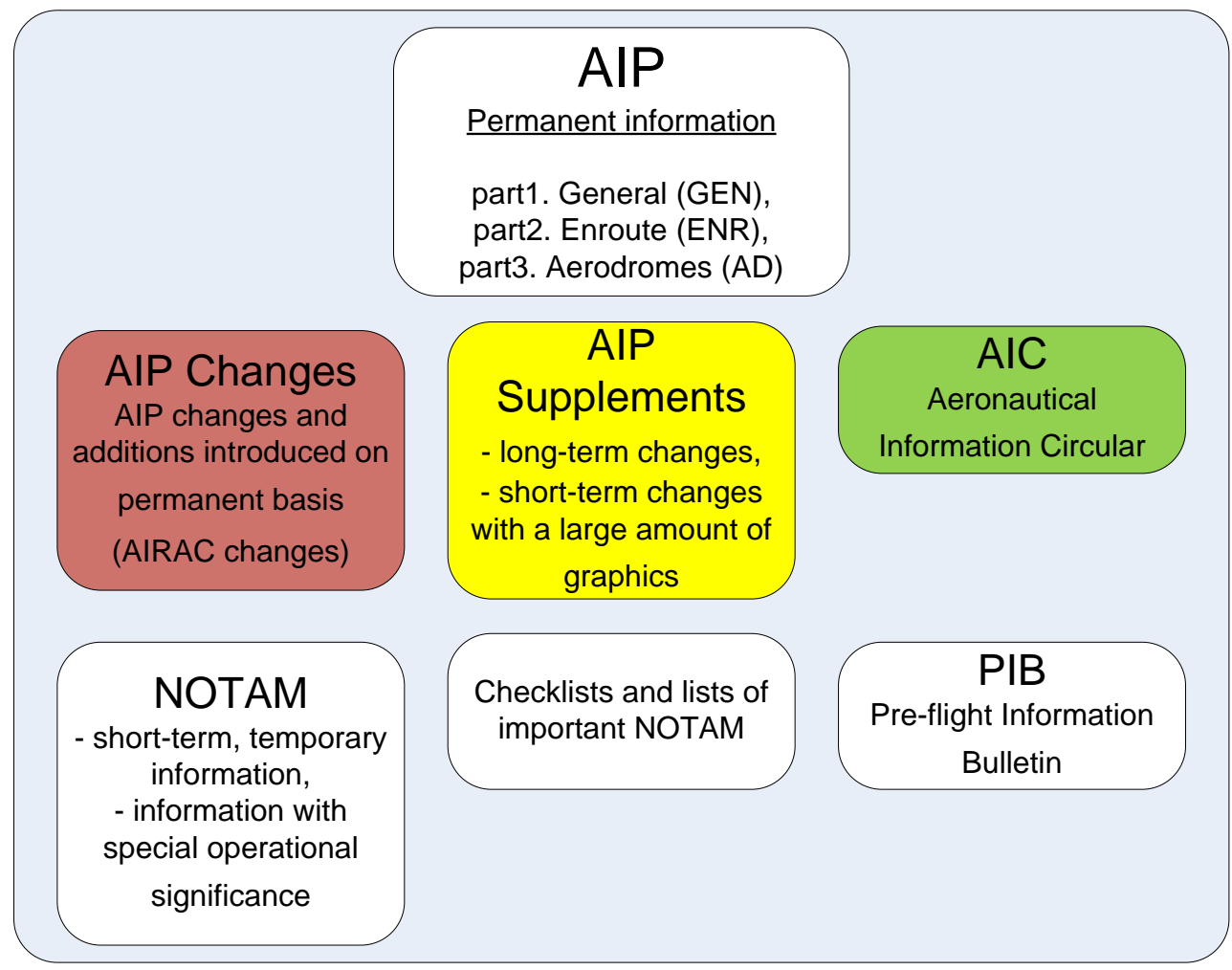

Fig. 1. Integrated Aeronautical Information Package [prepared by the Authors]

The basic document of the Integrated Aeronautical Information Package is the Aeronautical Information Publication - AIP, which is the main source of permanent information and temporary changes of a long-term character. It can be said that these are static data necessary to plan the flight in a safe way, and guidelines, orders and prohibitions included in the AIP Poland, are binding for all airspace users performing air operations in FIR Warsaw. 
Analysis of aeronautical information potential incompatibility - case study Analiza potencjalnej niezgodności informacji lotniczej-studium przypadku

The detailed structure and information content of Aeronautical Information Publication is defined in Appendix 1 to the ICAO Annex 15 [11].

AIP is published in two languages - usually in the language of the publishing state and in one of the ICAO languages.

AIP Poland is a publication consisting of three basic parts:

Part 1 - General (GEN), containing:

- in chapter GEN1: a description of national rules and requirements, including issues related to the arrival, transit or departure of aircrafts and passengers, a brief description of the instruments, equipment and documentation of aircrafts, as well as derogations from ICAO standards, recommended practices and procedures,

- in chapter GEN2: issues related to the relevant measurement units (including conversion tables), reference systems (temporal, vertical and horizontal), abbreviations used in publications and conventional signs on the maps, indicators of location, a list of radio navigation aids, as well as tables of sunrise and sunset,

- in chapter GEN3: description of provided air navigation services, including aeronautical information services, together with the scope of responsibility and published aeronautical maps, air traffic services, communication services, meteorological and search and rescue services,

- in chapter GEN4: charges for use of aerodromes/aerodromes for helicopters and for navigation services.

Part 2 - Enroute (ENR) contains, among others:

- chapter ENR1 - General Rules and Procedures: detailed Visual Flight Rules and Instrument Flight Rules, classification and description of ATS airspace, arrival and departure procedures, description of services and procedures of surveillance, procedures of altimeter setting, description of the air traffic flow and airspace management, procedures for flight planning, procedures related to the interception of civil aircraft and used in the event of unlawful interference, as well as a description of the system for reporting irregularities in air traffic,

- chapter ENR2 - Air Traffic Services Airspace: a detailed description of Flight Information Regions - FIR, Upper Flight Information Region - UIR, and Control Area - CTA, including Terminal Manoeuvring Areas - TMA,

- chapter ENR3 - ATS Routes: description of the ATS routes including a detailed description of upper and lower routes and area navigation routes, helicopters routes and en-route holding procedures,

- chapter ENR4 - Radio Navigation Aids and Systems: a detailed description of en-route radio navigation aids, special navigation systems (DECCA, LORAN, etc.), global navigation satellite system (GNSS), name-code designators for significant navigation points and en-route aeronautical ground lights, 
- chapter ENR5 - Navigation Warnings: list supplemented by graphical representation of prohibited, restricted and dangerous areas, zones of military exercises, traverse and air defence identification zones, description of activities of a dangerous character, list of air navigation obstacles, aerial sporting and recreational activities and bird migration and areas with sensitive fauna,

- chapter ENR6 - En-Route Charts.

Part 3 - Aerodromes (AD) containing a detailed description of aerodromes and conditions of use, airport services and procedures (a list of available aerodromes, geographical and administrative data, availability and terms of use, hours of work, services and facilities for ground handling and passengers, surface movement guidance and control system and markings, rescue and firefighting services, aerodrome obstacles, radio navigation and landing aids, together with a set of ICAO required charts related to an aerodrome.

In the two-volume AIP Poland publication, Volume I contains parts GEN - General information and ENR - Enroutes (a separate room is also provided for AIRAC changes as well as Aeronautical Information Circular - AIC). Volume II covers part AD - Aerodromes. Because of the importance and utilization of the described information, their accuracy, completeness, consistency, and timeliness (or generally said - quality), as mentioned earlier, is crucial for ensuring safe aeronautical operations.

\section{Visual docking system}

Characteristics, requirements and recommendations for the visual docking system are defined in Annex 14 to the Convention on International Civil Aviation [10]. According to the specifications and notes a visual docking guidance system shall be provided: ,when it is intended to indicate, by a visual aid, the precise positioning of an aircraft on an aircraft stand and other alternative means, such as marshallers, are not practicable. The factors to be considered in evaluating the need for a visual docking guidance system are in particular: the number and type(s) of aircraft using the aircraft stand, weather conditions, space available on the apron and the precision required for manoeuvring into the parking position due to aircraft servicing installation, passenger loading bridges, etc.".

Standard Visual Docking Guidance Systems - VDGS are used since 1970. to improve safety at the gate. Commonly used VDGS solution is based on the interaction of a human - the operator and automation systems to guide pilots nosein and stop aircraft in precise positions (allowing proper loading of bridges, fuel pits and ground-based units). Standard docking system shall provide both azimuth and stopping guidance in the determined position. The azimuth guidance unit and the stopping position indicator shall be adequate for use in all weather, visibility, background lighting and pavement conditions for which the system is intended, both by day and night, but shall not dazzle the pilot.

The level of automation varies by manufacturer, but the docking guidance itself uses a passive technology and each docking is started manually with a ground agent selecting the proper aircraft type and supervising positioning of an aircraft on an aircraft stand. 
Analysis of aeronautical information potential incompatibility - case study Analiza potencjalnej niezgodności informacji lotniczej-studium przypadku

The new generation of docking guidance equipment, classified by ICAO as Advanced Visual Docking Guidance Systems (A-VDGS) are fully automated solutions. ICAO Annex 14 [10] defines them as systems providing pilots the following information: basic and passive azimuth and stop position information, aircraft's type indication, distance-to-go as well as closing speed. The most popular A-VDGS systems provide information based on the three-step laser scanning (although guidance systems using optical cameras are also used). Those three stages of docking guidance information are: the acquisition of the aircraft by the system, the azimuth alignment of the aircraft, and the stopping position information, all brought into a single multicolour LED display (Figure 2).

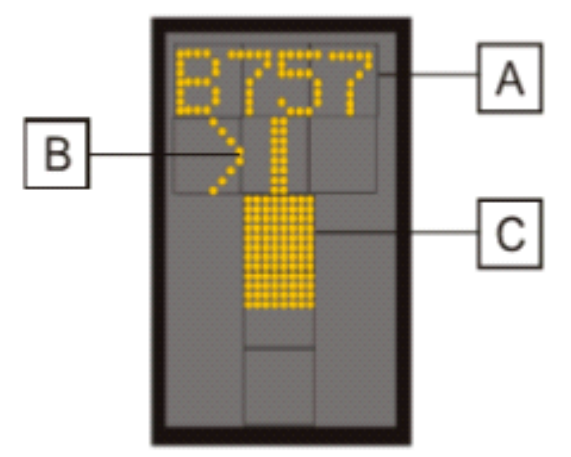

\section{A - Alphanumeric display $B$ - Azimuth guidance C - Approach distance field}

Fig. 2. Advanced docking guidance system's (A-VDGS) display [reference: 9 - AIP Poland, part AD, aerodrome EPGD]

According to the requirement 5.3.25.6. of ICAO Annex 14 [10] the A-VDGS shall provide, at minimum, the following guidance information at the appropriate stage of the docking manoeuvre:

- an emergency stop indication;

- the aircraft type and model for which the guidance is provided;

- an indication of the lateral displacement of the aircraft relative to the stand centre line;

- the direction of azimuth correction needed to correct a displacement from the stand centre line;

- an indication of the distance to the stop position;

- an indication when the aircraft has reached the correct stopping position;

- a warning indication if the aircraft goes beyond the appropriate stop position.

Exemplary indications of the A-VDGS system are show on Figure 3. 


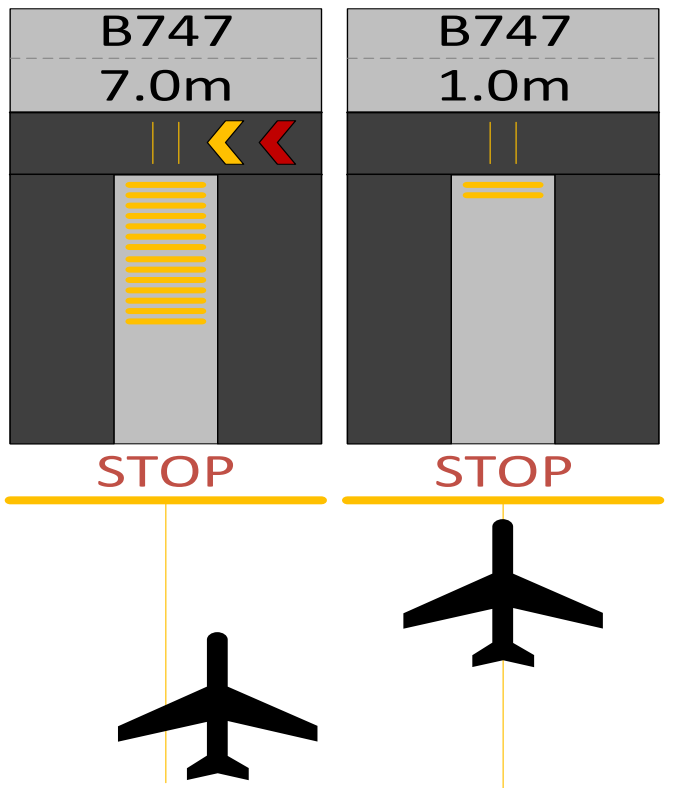

Fig. 3. Exemplary indications of the A-VDGS system [prepared by the Authors]

\section{Aeronautical information potential incompatibility - case study}

The aeronautical information publication AIP Poland [9] part 3 - Aerodromes lists and characterizes 23 Polish aerodromes. As the effect of this document's analysis, focusing on the considered and discussed aircrafts' advanced visual docking guidance systems A-VDGS, it was fund that the system at the moment is installed and operates at three Polish aerodromes - in Gdańsk (EPGD), Warsaw (EPWA) and Wrocław (EPWR). At all three mentioned aerodromes, the procedure of operation, described in the AIP Poland, is analogous:

- check that the correct aircraft type is displayed on the display and then follow the lead-in line;

- drifting arrows (in fields B and C - figure 2) indicate that the system has been activated and the approaching aircraft is being captured by the system, while appearance of the yellow approach indicator field indicates that the aeroplane has been identified by the system;

- the red and yellow azimuth guidance arrows should be observed, the yellow arrows on both sides of the centre line indicate the correct azimuth position;

- at a specified distance (for each aerodrome) from the stop position, the remaining distance to go is indicated by switching off successive rows of LED indicators - figure 2 (for EPGD aerodrome - the display shows also the number of remaining metres to go, while for EPWA and ERWR aerodromes each switched-off row is equal to $0.5 \mathrm{~m}$ of the traversed distance);

- reaching the correct stop position is indicated by displaying a STOP message and red rectangular on the outer edges of the centre line lead field;

- when the aeroplane is docked in the correct position, the display will show an OK message after a few seconds. 
Analysis of aeronautical information potential incompatibility - case study Analiza potencjalnej niezgodności informacji lotniczej-studium przypadku

Authors attention was drawn to the fulfilment of the requirement 5.3.25.12 of ICAO Annex 14 [10], saying that ,continuous closure distance and closure rate shall be provided from at least $15 \mathrm{~m}$ prior to the stop position". For aerodrome EPGD - Gdańsk, AIP Poland states: „At a distance of 15 metres from the stop position, the remaining distance to go is indicated by switching off successive rows of LED indicators. The display shows also the number of remaining metres to go". For aerodrome EPWR - Wrocław - Strachowice can be read that: „At a distance of $30 \mathrm{~m}$ from the docking position, the approach distance indicator shows to the pilot the remaining distance by switching off successive rows of LED indicators. Each switched-off row is equal to $0.5 \mathrm{~m}$ of the traversed distance".

For aerodrome EPWA - Chopin in Warsaw AIP information states that: „At a distance of 12 metres from the stop position, the remaining distance to go is indicated by switching off successive rows of LED indicators. Each switched-off row is equal to $0.5 \mathrm{~m}$ of the traversed distance. Switching off all rows of LEDs means 0.5 metre distance to the docking point".

Information published in AIP Poland for Gdańsk and Wrocław aerodromes do not raise Authors' doubts, although AIP Poland records, concerning the automatic docking system "Safegate" do not mention the approach speed, which, in accordance with valid requirements, should also be provided continuously. For the aerodrome in Warsaw (EPWA) a discrepancy between the requirements (to make it short: $15 \mathrm{~m}$ from the stop position) concerning the A-VDGS system published in ICAO Annex 14 [10], and the information published in AIP Poland (12 meters from the stop position) was found. In this situation, the Authors ask themselves about the possible cause, source, place and manner of materialization of this incompatibility. Knowing that the data and information error can occur at any stage of aeronautical data and information supply chain [2], both in phases of data request, origination, evaluation, approval, preparation, distribution, as well as their end-use, and its causes, source, place, and manner of materialization may differ, the Authors used the described case as an example to justify the purpose and direction of the work undertaken in the field of aeronautical data and information quality assurance.

\section{Potential incompatibility analysis}

It should be stated that the case described above Authors analysed theoretically only, abandoning execution of analysis of the facts.

The detected discrepancy of information published in AIP Poland with the requirements of ICAO Annex 14 [10] may, but need not be an incompatibility, if this deviation has been formally approved - information about that fact is subject to notification to the ICAO Council and should be published in ICAO Annex 14, as well as in AIP Poland.

Assuming for further considerations that in a formal sense the analysed case is an inconsistency, it is necessary to determine the fundamental question of the incompatibility's place of appearance - whether this incompatibility refers to the parameters of the A-VDGS system and information published in AIP Poland is correct?, or whether the parameters of the A-VDGS system do not meet the requirements of ICAO Annex 14, and information published in AIP Poland is correct? The formulation of this problem implies an important observation concerning the need to discover the actual status and location of the mentioned 
inconsistency in case of potential aeronautical data and information incompatibility appearance.

Assuming in further consideration, that the actual parameters of the A-VDGS system comply with the requirements of ICAO Annex 14 [10], further analysis of the aeronautical data and information chain (Figure 4), which is the subject of previous Authors' research and publications $[3,5]$, in particular the scheme of data and information origination (Figure 5), containing only the element of final verification, which, as it must be assumed in this case, proved to be ineffective or omitted, should be conducted.

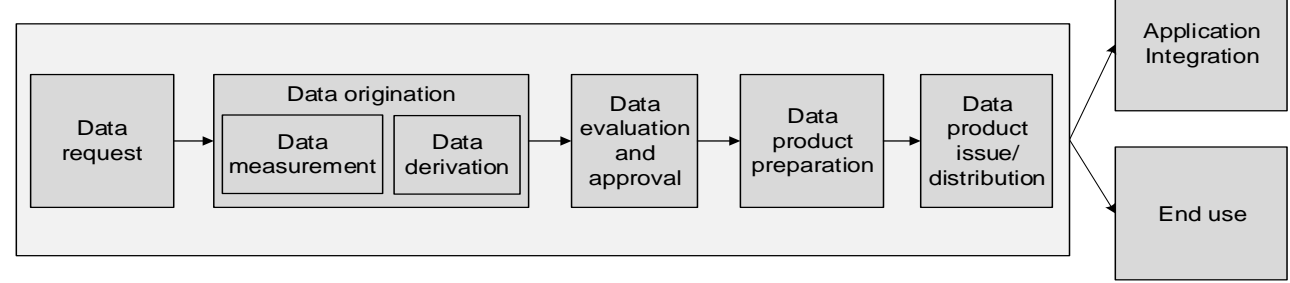

Fig. 4. Aeronautical data chain (based on [8])

Leading the analysis of the mentioned incompatibility in accordance with the formally valid schemes of aeronautical data and information origination and publication (Figure 4, 5) the Authors drew attention to the fact that this inconsistency was identified only after its publication in the AIP Poland, which means at the stage of aeronautical information final use (Figure 4).

In this case, the analysis of the incompatibility, starting with the determination of its occurrence place and then its causes as well as determination of the adequate preventive and corrective measures, should be carried out using the "upstream" method, taking into account that in the extreme case, the occurrence of the noncompliance may have occurred at the stage of data request (Figure 4) or sharing of source data e.g. the producer's documentation and/or A-VDGS system provider.

Analysis of the presented scheme (Figure 5) leads to the obvious conclusion that its use in practice makes the uninterrupted identification of incompatibilities impossible, as well as hinders the subsequent determination of the place/stage where the mismatch occurred (the "NO" result in step 4). Analysing each step, it is necessary to determine the compatibility of input data, method and the processing result (measurement, analysis, redaction, editing, formatting), as well as finally the compatibility of the output data. Moreover, further verification of input and output data compatibility between successive stages is necessary. Taking into account the date of publication, the Authors point out that, in practice, this will involve the need to download data and records already archived, which will result in the need for time-consuming determination of the place of incompatibility appearance and the possible introduction of operating restrictions, until the end of analysis conduction and implementation of corrective and preventive actions. But planning of these activities will also be time-consuming because of the need to prove causes of the inconsistency, e.g. using Ishikawa diagram [7], and then the need to determine the possible ways to prevent a recurrence of the incompatibilities and ways to reduce the size of their effects [6]. 
Analysis of aeronautical information potential incompatibility - case study Analiza potencjalnej niezgodności informacji lotniczej-studium przypadku

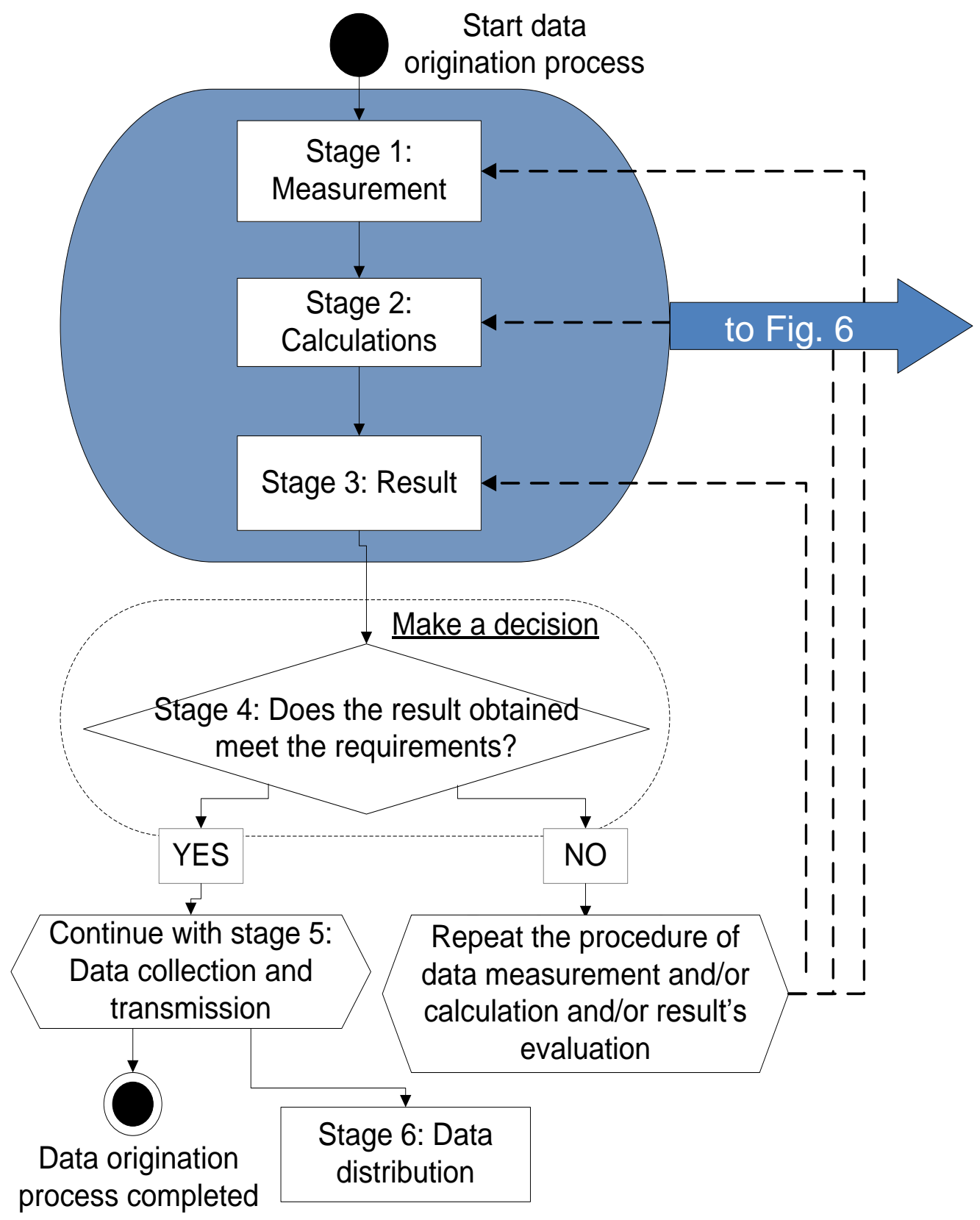

Fig. 5. Diagram of data origination process with final evaluation [prepared by the Authors] 


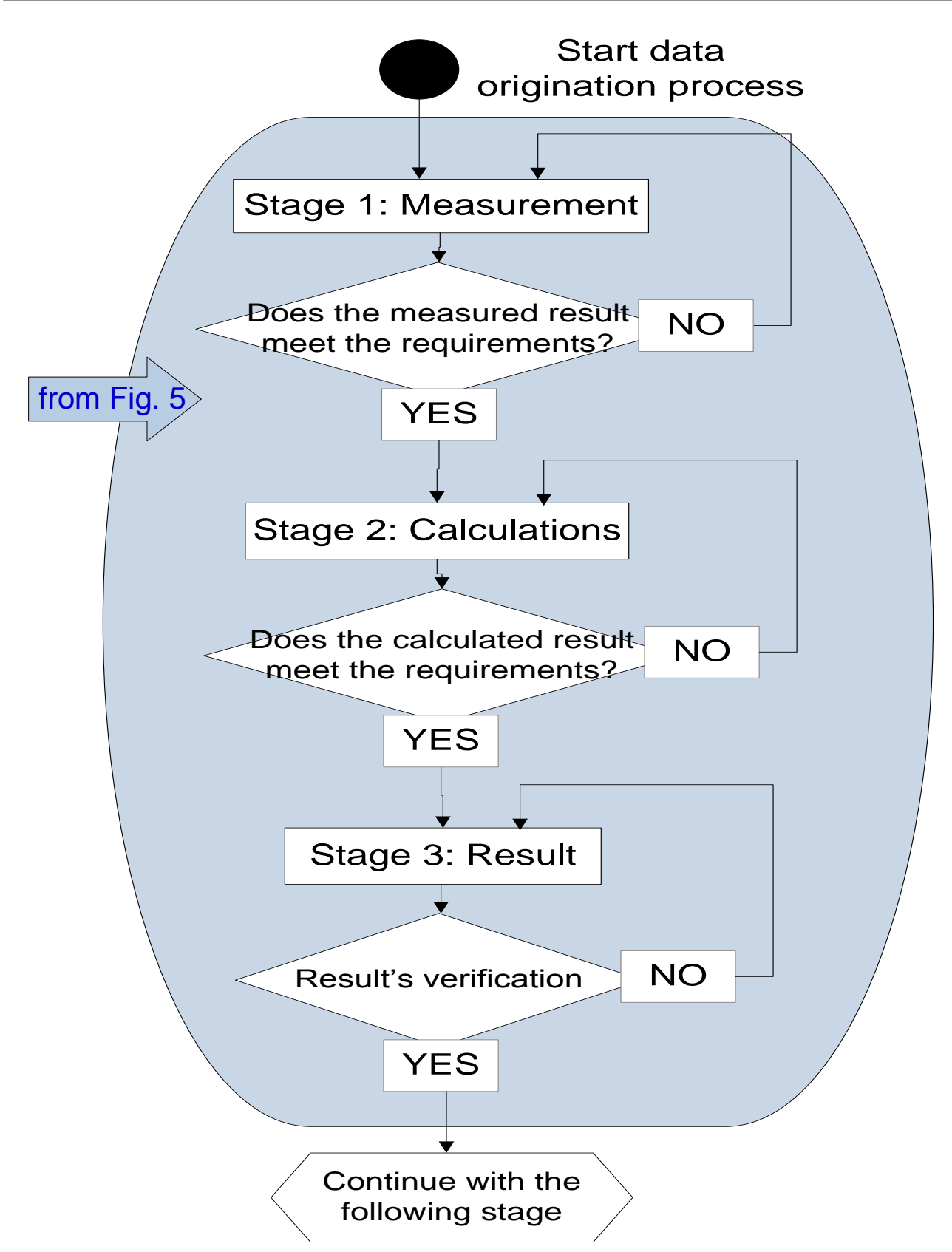

Fig. 6. Diagram of data origination process with staged evaluation[prepared by the Authors] 
Analysis of aeronautical information potential incompatibility - case study Analiza potencjalnej niezgodności informacji lotniczej-studium przypadku

Therefore, the Authors in one of the previous publications [3] proposed a modification to the scheme of aeronautical data origination by introducing into each stage the verification and validation procedures (Figure 6), so that a potential or real incompatibility is identified up to date, and planning and implementation of preventive and correction actions occupies much less time.

\section{Summary}

Air transport is a domain containing a great number of formally published restrictions, specifications, requirements, and procedures to ensure the highest level of air operations' safety. Also (in accordance with these regulations) activities taken under the aeronautical data and information chain as well as entities participating in them are subject to control and certification. Despite such an extensive surveillance system, numerous verification procedures it happens that incorrect aeronautical data or information are transmitted to end-users such as aviation personnel and the cause, source, place and manner of incompatibilities' materialization are difficult to determine immediately.

This is largely due to the fact that the published requirements, specifications and algorithms introduce only the obligation to execute the verification at the end of the process. There is a lack of verification procedures at the succeeding stages (this issue is discussed wider in another work of the Authors [3]) and algorithms for the assessment and evaluation of the quality of aeronautical data and information in all phases of their existence. The example of potential incompatibility in an aviation publication, indicated in this article, confirms the need to develop and implement a comprehensive method of ensuring quality (evaluation and monitoring, evaluation and validation) of aeronautical data and information at all stages of aeronautical data and information chain, which will be subject of Authors' further work and at the same time justifies the previously formulated thesis regarding the purpose and direction of the necessary projects.

\section{References}

[1] Dudek E., Kozłowski M.: Koncepcja procesu oceny jakości danych lotniczych, Prace Naukowe Politechniki Warszawskiej - Transport, z. 113, str. 131-140, Warszawa 2016, nr ISSN: 1230-9265.

[2] Dudek E., Kozłowski M.: Koncepcja zarządzania jakością danych lotniczych, Prace Naukowe Politechniki Warszawskiej - Transport, z. 113, str. 141-150, Warszawa 2016, nr ISSN: 1230-9265.

[3] Dudek E., Kozłowski M.: Koncepcja zastosowania metodyki DMAIC do zapewnienia jakości danych lotniczych, [w] Kwasiborska A. (red.): Transport lotniczy i jego otoczenie, Wydział Transportu Politechniki Warszawskiej, str. 67-78, Warszawa 2016, nr ISBN: 978-83-7814-548-6.

[4] Dudek E., Kozłowski M.: The concept of a method ensuring aeronautical data quality, Journal of KONBiN No 1(37)2016, str. 319-340, Warszawa 2016, nr ISSN: $1895-8281$. 
[5] Kozłowski M., Dudek E.: NOTAM jako bariera bezpieczeństwa informacji lotniczych, artykuł złożony do druku w ramach VI Międzynarodowej Konferencji Naukowej Bezpieczeństwo w portach lotniczych i morskich, Dęblin, wrzesień 2016.

[6] Kozłowski M., Malarski M.: Metody badania przyczyn i skutków zagrożenia bezpieczeństwa ruchu lotniskowego, XXXIII ZSN, Szczyrk 2005 r.

[7] Kozłowski M., Winiewski A.: Diagram Ishikawy w systemie zarządzania bezpieczeństwem w porcie lotniczym, XXXIV ZSN, Szczyrk 2006 r.

[8] Eurocontrol Specification for Data Assurance Levels, Document Identifier: EUROCONTROL-SPEC-0148.

[9] www.ais.pata.pl/aip (access date November $8^{\text {th }}$ 2016).

[10] ICAO Annex 14 to the Convention on International Civil Aviation, Aerodromes, volume I, International Civil Aviation Organization, July 2009.

[11] ICAO Annex 15 to the Convention on International Civil Aviation, Aeronautical Information Services, International Civil Aviation Organization, July 2013.

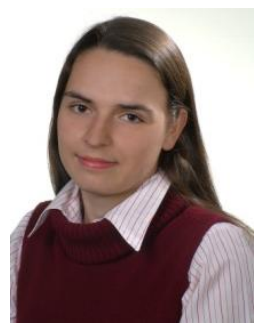

mgr in. Ewa Dudek works as an assistant in the Telecommunication Department at Warsaw University of Technology, Faculty of Transport. Scientific interests cover transport telematics, system integration, issues related to air traffic control as well as automation of continuous processes (Share 50\%).

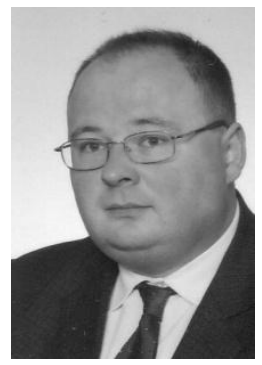

Michat Kozlowski - Assistant Professor in the Department of Air Transport Engineering at Warsaw University of Technology, Faculty of Transport. Extensive experience in airport managing, gained from over twenty years of work in the operating area of Warsaw Chopin Airport. Author of numerous studies, publications and implementations in the field of safety, quality, reliability and capacity (Share 50\%). 


\section{ANALIZA POTENCJALNEJ NIEZGODNOŚCI INFORMACJI LOTNICZEJ - STUDIUM PRZYPADKU}

\section{Wprowadzenie}

Transport lotniczy jest dziedziną rozwijającą się bardzo dynamicznie. Wynikające z tego działania, ukierunkowane na zwiększanie przepustowości przestrzeni powietrznej, nie mogą jednak odbywać się kosztem bezpieczeństwa ruchu lotniczego, a jedynie $\mathrm{z}$ usprawnieniem systemów transmisji informacji. W zarządzaniu ruchem lotniczym (ATM) obserwuje się coraz większy stopień uzależnienia od systemów telematycznych ( $\mathrm{w}$ szczególności tych związanych $\mathrm{z}$ wymianą danych $\mathrm{i}$ transmisją informacji). Wymagania, procedury i przepisy wykonawcze obowiązujące w lotnictwie cywilnym, omówione szerzej w innych pracach Autorów [1,2,4], mają na celu zapewnienie odpowiedniego poziomu bezpieczeństwa operacji lotniczych. Jako iż efektywność i skuteczność funkcjonowania transportu lotniczego jest w ogromnym stopniu uzależniona od dostarczania informacji odpowiedniej jakości, w poprzednich pracach (np. [2, 3]) Autorzy zaproponowali kompleksowe i systemowe podejście do zapewnienia jakości na wszystkich etapach łańcucha danych i informacji lotniczych. Zwrócili również uwagę na fakt, iż, mimo że nieintencjonalne błędy ludzkie stanowią statystycznie dominującą przyczynę zdarzeń lotniczych, to w statystykach tych zdarzeń mamy również do czynienia $\mathrm{z}$ przypadkami prawidłowego działania człowieka (np.: pilota, czy kontrolera ruchu lotniczego) lub systemu, w oparciu o dane obarczone błędem, który wystąpił i nie został zidentyfikowany oraz skorygowany na którymkolwiek $\mathrm{z}$ etapów tworzenia, gromadzenia lub przetwarzania [5]. Należy mieć również świadomość, iż błąd danych może wystąpić na każdym etapie łańcucha dostaw danych i informacji lotniczych [2], również w fazach transferu, publikacji oraz interpretacji, a jego przyczyny, źródło czy też miejsce i sposób materializacji mogą być skrajnie różne. Co więcej, samo wystąpienie błędu w danych lotniczych nie musi być (i najczęściej niestety nie jest) identyfikowane w chwili (lub miejscu) jego wystąpienia.

Niniejsza publikacja stanowi kontynuację prac Autorów nad zagadnieniem zapewnienia jakości danych i informacji lotniczych $w$ całym procesie (rozpatrywanym jako łańcuch dostaw) ich tworzenia, gromadzenia, przetwarzania i publikacji. Przedstawiono w niej Zintegrowany Pakiet Informacji Lotniczych oraz szerzej opisano jego podstawową część - Zbiór Informacji Lotniczych (AIP Polska), będący jednym z podstawowych dokumentów lotniczych, podkreślając, iż informacje $\mathrm{w}$ nim zawarte, stanowiące bazę do planowania i bezpiecznego wykonania lotu, muszą zawsze być aktualne i gotowe do użycia. Ponadto w artykule szerzej omówiono zaawansowany wzrokowy system dokowania (ang. Advanced Video Docking Guidance System - A-VDGS), będący przykładem zastosowania systemu telematyki w transporcie lotniczym. 
Przedstawiono wymagania $\mathrm{z}$ nim związane oraz rysunki poglądowe, mając na uwadze, iż niezawodność działania takiego systemu oraz poprawność wyświetlanych przezeń informacji ma bezpośredni wpływ na bezpieczeństwo operacji kołowania i ustawiania statku powietrznego na określonym stanowisku postojowym.

Przeprowadzone w niniejszej pracy studium przypadku ilustruje stopień złożoności analizowanego zagadnienia zapewnienia jakości informacji lotniczych.

\section{Zintegrowany Pakiet Informacji Lotniczych}

Dane i informacje lotnicze publikowane są w celu zapewnienia bezpiecznej i regularnej żeglugi powietrznej, zgodnie ze szczegółowymi wymaganiami Załącznika 15 ICAO [11], który określa rodzaj informacji, jakie mają być udostępniane, oraz związane $\mathrm{z}$ nimi wymagania jakościowe. $\mathrm{Z}$ punktu widzenia zagadnień, poruszanych $\mathrm{w}$ niniejszej publikacji, szerszego omówienia wymaga Zintegrowany Pakiet Informacji Lotniczych (rysunek 1), zapewniany przez Służbę Informacji Lotniczej Polskiej Agencji Żeglugi Powietrznej. Ponieważ Pakiet ten jest jednym $\mathrm{z}$ podstawowych dokumentów lotniczych stanowiących bazę do planowania i bezpiecznego wykonania lotu, informacje w nim zawarte muszą zawsze być poprawne, aktualne i gotowe do użycia.

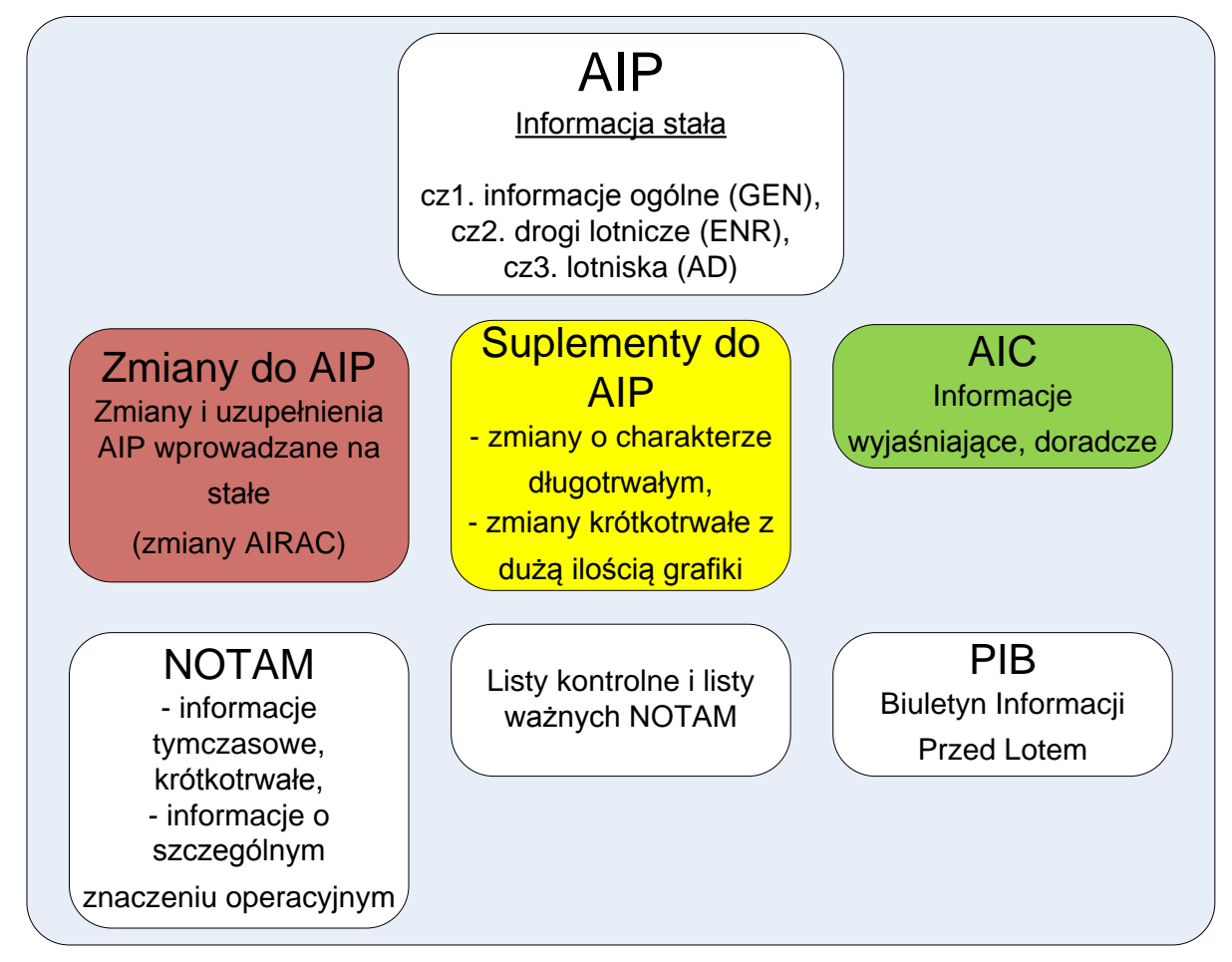

Rys. 1. Zintegrowany Pakiet Informacji Lotniczych [opracowanie własne] 
Analysis of aeronautical information potential incompatibility - case study Analiza potencjalnej niezgodności informacji lotniczej-studium przypadku

Podstawowym dokumentem Zintegrowanego Pakietu Informacji Lotniczych jest Zbiór Informacji Lotniczych - AIP (ang. Aeronautical Information Publication), stanowiący główne źródło informacji stałych i informacji o czasowych zmianach o charakterze długotrwałym. Można więc powiedzieć, że są to dane statyczne niezbędne do zaplanowania lotu w sposób bezpieczny, a zawarte w AIP Polska wskazówki, nakazy czy zakazy są wiążące dla wszystkich podmiotów wykonujących operacje lotnicze w przestrzeni powietrznej naszego kraju (FIR Warszawa). Szczegółowa struktura i zawartość informacyjna Zbioru Informacji Lotniczych zdefiniowana jest $\mathrm{w}$ Dodatku 1 do Załącznika 15 ICAO [11]. AIP publikowane jest w dwóch językach - zazwyczaj w języku państwa publikującego oraz w jednym $\mathrm{z}$ języków ICAO.

AIP Polska jest publikacją składającą się z trzech podstawowych części:

Część 1 - Informacje ogólne (ang. General - GEN), zawierająca:

- w rozdziale GEN1: opis krajowych przepisów i wymagań, w tym zagadnienia związane z przylotem, tranzytem czy odlotem statków powietrznych oraz pasażerów, zwięzły opis przyrządów, wyposażenia i dokumentacji statków powietrznych, jak również odstępstwa od norm, zalecanych metod postępowania i procedur ICAO,

- w rozdziale GEN2: zagadnienia związane ze stosowanymi jednostkami miar (w tym tabele przeliczeniowe), układami odniesienia (czasowy, pionowy i poziomy), skróty stosowane w publikacjach oraz znaki umowne na mapach, wskaźniki lokalizacji, wykaz pomocy radionawigacyjnych, jak również tabele wschodu i zachodu słońca,

- w rozdziale GEN3: opis zapewnianych służb żeglugi powietrznej, w tym służby informacji lotniczej wraz z zakresem odpowiedzialności oraz publikowanych map lotniczych, służb ruchu lotniczego, służby łączności, meteorologicznej oraz służby poszukiwania i ratownictwa,

- w rozdziale GEN4: opłaty za korzystanie z lotnisk/lotnisk dla śmigłowców oraz za usługi nawigacyjne.

Część 2 - Drogi lotnicze (ang. Enroute - ENR) zawiera między innymi:

- rozdział ENR1: szczegółowe przepisy lotów z widocznością oraz według wskazań przyrządów, klasyfikację i opis przestrzeni powietrznej ATS, procedury oczekiwania, przylotu i odlotu, opis służb i procedur dozorowania, procedury nastawiania wysokościomierzy, opis systemu zarządzania przepływem ruchu lotniczego i przestrzenią powietrzną, procedury planowania lotów, procedury związane $\mathrm{z}$ przechwytywaniem cywilnych statków powietrznych oraz stosowane $\mathrm{w}$ razie zaistnienia bezprawnej ingerencji, jak również opis systemu zgłaszania nieprawidłowości w ruchu lotniczym,

- rozdział ENR2: szczegółowy opis rejonów informacji powietrznej (FIR), górnych rejonów informacji powietrznej (ang. Upper Flight Information Region - UIR) oraz rejonów kontrolowanych (ang. Control Area - CTA), w tym 
szczególne rejony kontrolowane lotnisk cywilnych (ang. Terminal Manoeuvring Area - TMA),

- rozdział ENR3: opis dróg lotniczych ATS w tym szczegółowy opis tras dolnych i górnych, dróg nawigacji obszarowej, tras dla śmigłowców i procedur oczekiwania na trasie,

- rozdział ENR4: pomoce i systemy radionawigacyjne w tym: nazwy kodowe oznaczników dla znaczących punktów nawigacyjnych czy też trasowe lotnicze światła naziemne,

- rozdział ENR5: spis uzupełniony o graficzne przedstawienie stref zakazanych, ograniczonych i niebezpiecznych, stref ćwiczeń wojskowych, poligonów oraz strefy identyfikacyjnej obrony powietrznej, opis działań o charakterze niebezpiecznym, spis przeszkód lotniczych,

- rozdział ENR6: zestawienie map trasowych ICAO.

Część 3 - Lotniska (ang. Aerodromes - AD) zawierająca dokładny opis lotnisk, służb i procedur lotniskowych (wykaz dostępnych lotnisk, dane geograficzne i administracyjne, dostępność i warunki korzystania, godziny pracy, ułatwienia dla pasażerów, systemy kierowania ruchem naziemnymi oznakowanie, itd.), wraz $\mathrm{z}$ kompletem wymaganych map.

W dwutomowej publikacji AIP Polska Tom I zawiera części GEN - Informacje ogólne oraz ENR - Drogi Lotnicze (wydzielono w nim także miejsce na przechowywanie Zmian AIRAC oraz Biuletynów Informacji Lotniczej (AIC)). Zaś Tom II obejmuje część AD - Lotniska. Ze względu na wagę i zastosowanie opisanych informacji, ich dokładność, kompletność, spójność i terminowość (czyli ogólnie rzecz biorąc - jakość), jak wspomniano wcześniej, ma kluczowe znaczenie dla zapewnienia bezpieczeństwa wykonywanych operacji lotniczych.

\section{Wzrokowy system dokowania}

Charakterystyka, zastosowanie oraz wymagania i zalecenia dotyczące wzrokowego systemu dokowania określone są $\mathrm{w}$ Załączniku 14 do Konwencji o międzynarodowym lotnictwie cywilnym [10]. Zgodnie $\mathrm{z}$ zawartymi tam specyfikacjami i uwagami powinien on być instalowany, ,gdy przy użyciu pomocy wzrokowych zamierza się wskazać dokładną pozycję ustawienia statku powietrznego na stanowisku postojowym, a inne alternatywne rozwiązania, takie jak wykorzystanie sygnalistów nie jest praktyczne do zastosowania. Czynnikami, które należy brać pod uwagę przy ocenie potrzeby zainstalowania wzrokowego systemu dokowania są między innymi: ilość i typ(y) statków powietrznych, które będą użytkować stanowisko postojowe, warunki meteorologiczne, dostępna powierzchnia na płycie postojowej i wymagana dokładność ustawienia na stanowisku postojowym, ze względu na instalacje służące do obsługi statku powietrznego, rękawy pasażerskie, itd.”.

Standardowe wzrokowe systemy dokowania statków powietrznych (ang. Visual Docking Guidance System - VDGS) wykorzystywane są od lat 70 . w celu poprawy bezpieczeństwa operacji statków powietrznych na płycie. 
Analysis of aeronautical information potential incompatibility - case study Analiza potencjalnej niezgodności informacji lotniczej-studium przypadku

Powszechnie stosowane rozwiązania oparte są na współdziałaniu człowieka operatora i układów automatyki, w celu przekazywania pilotowi danych i informacji zapewniających bezpieczne i prawidłowe ustawienie samolotu na stanowisku postojowym, w określonej pozycji (umożliwiającej prawidłowe przystawienie końcówki pomostu pasażerskiego i przyłączenie złączy systemów i agregatów naziemnych). Standardowy system dokowania musi więc zapewniać prowadzenie kierunkowe oraz zatrzymanie statku powietrznego w określonej pozycji. Jednostka prowadzenia kierunkowego oraz wskaźnik pozycji zatrzymania muszą być przystosowane do wykorzystania w każdych warunkach pogodowych, widzialności, oświetlenia tła oraz stanu nawierzchni, dla których ten system jest przeznaczony, zarówno w dzień jak i w nocy, przy tym nie może oślepiać pilota. Poziom automatyzacji zależy od producenta danego systemu, zaś sam system dokowania wykorzystuje technologię pasywną, a manewr dokowania rozpoczynany jest przez personel służb obsługi naziemnej, określający typ samolotu i nadzorujący ustawianie statku powietrznego na stanowisku postojowym.

Systemy nowszej generacji, sklasyfikowane przez ICAO jako Zaawansowane wzrokowe systemy dokowania (ang. Advanced Visual Docking Guidance System A-VDGS), są rozwiązaniami w pełni zautomatyzowanymi. Załącznik 14 ICAO [10] określa je, jako systemy zapewniające pilotowi następujące informacje: informacje o bazowym i pasywnym azymucie oraz o punkcie zatrzymania, wskazanie typu statku powietrznego, odległość do pokonania i końcową prędkość. Najbardziej popularne systemy A-VDGS przekazują informację dotyczącą naprowadzania do dokowania na podstawie trójstopniowego skanowania laserowego (choć stosowane są również układy naprowadzania wykorzystujące kamery optyczne): gdy system namierza statek powietrzny, gdy określa jego azymutalne położenie i gdy przekazuje informację o miejscu zatrzymania, sprowadzając niezbędne informacje do pojedynczego wielokolorowego wyświetlacza LED (rysunek 2).

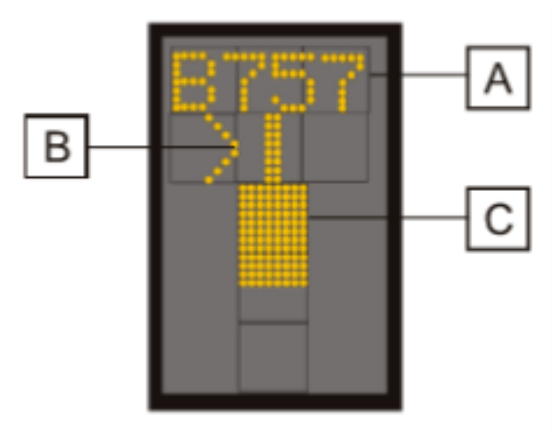
A - Wyświetlacz alfanumeryczny
B - Naprowadzanie azymutalne C - Pole wskaźnika zbliżania

Rys. 2. Wyświetlacz zaawansowanego wzrokowego systemu dokowania A-VDGS [źródto: 9 - AIP Polska, część AD, lotnisko EPGD] 
Zgodnie z wymaganiem 5.3.25.6. Załącznika 14 ICAO [10] w stosownym momencie manewru dokowania system A-VDGS musi zapewniać, co najmniej, następujące informacje dotyczące naprowadzania:

- wskazanie punktu zatrzymania awaryjnego;

- określenie typu i modelu statku powietrznego, dla którego wykonywane jest naprowadzanie;

- wskazanie wielkości bocznego przemieszczenia statku powietrznego względem osi stanowiska postojowego;

- kierunek azymutalnej korekty niezbędnej dla skorygowania przemieszczenia względem osi stanowiska postojowego;

- wskazanie odległości do miejsca zatrzymania;

- wskazanie momentu osiągnięcia przez statek powietrzny prawidłowego miejsca zatrzymania;

- wskazanie ostrzegające, jeśli statek powietrzny przemieszcza się poza właściwe miejsce zatrzymania.

Przykładowe wskazania systemu A-VDGS przedstawiono na rysunku 3.

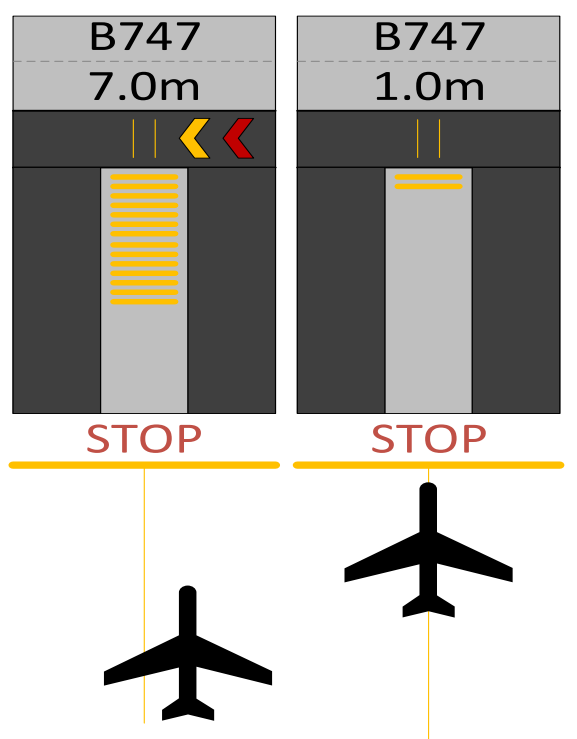

Rys. 3. Przykladowe wskazania systemu A-VDGS [źródto: opracowanie własne]

\section{Potencjalna niezgodność informacji lotniczej - studium przypadku}

W zbiorze informacji lotniczych AIP Polska [9] część 3 - Lotniska wymieniono i scharakteryzowano 23 polskie lotniska. W wyniku przeprowadzonej analizy tej publikacji pod kątem będącego przedmiotem rozważań zaawansowanego wzrokowego systemu dokowania statków powietrznych A-VDGS, stwierdzono, iż system ten na chwilę obecną zainstalowany jest i funkcjonuje na trzech polskich 
Analysis of aeronautical information potential incompatibility - case study Analiza potencjalnej niezgodności informacji lotniczej-studium przypadku

lotniskach - w Gdańsku (EPGD), w Warszawie (EPWA) oraz we Wrocławiu (EPWR). Na wszystkich trzech wymienionych lotniskach, zasada postępowania, opisana w AIP Polska, jest analogiczna:

a) należy sprawdzić czy na wyświetlaczu wyświetla się poprawny żądany typ samolotu, a następnie kołować zgodnie z linią prowadzącą;

b) przesuwające się strzałki (w polu B oraz C - rysunek 2) wskazują uaktywnienie się systemu oraz przechwytywanie zbliżającego się statku powietrznego, zaś wyświetlenie się żółtego pola wskaźnika zbliżania oznacza przechwycenie samolotu przez system;

c) należy obserwować czerwone i żółte strzałki naprowadzania kierunkowego, żółte strzałki po obu stronach żółtej linii centralnej oznaczają właściwą pozycję azymutalną;

d) w określonej (dla danego lotniska) odległości od miejsca zatrzymania wyświetla się dystans do przebycia poprzez wyłączenie kolejnych rzędów wskaźników LED - rysunek 2 (dla lotniska EPGD - na wyświetlaczu podana również zostaje wartość liczbowa $([\mathrm{m}])$ wyrażająca odległość do punktu zatrzymania, dla lotnisk EPWA oraz EPWR - wyłączenie jednego rzędu oznacza przebycie dystansu $0,5 \mathrm{~m}$ );

e) osiągnięcie przez samolot prawidłowej pozycji zatrzymania sygnalizuje pojawienie się na wyświetlaczu komunikatu STOP oraz czerwonych prostokątów na zewnętrznych krawędziach pola prowadzenia azymutalnego;

f) gdy samolot zostanie prawidłowo zatrzymany, po kilku sekundach na wyświetlaczu pojawi się komunikat OK.

Uwagę Autorów zwraca spełnienie wymagania 5.3.25.12 Załącznika 14 ICAO [10], stanowiącego, iż „od chwili gdy odległość (statku powietrznego - przyp. aut.) do miejsca zatrzymania wynosi co najmniej $15 \mathrm{~m}$ informacja o odległości do pokonania i o prędkości zbliżania musi być zapewniana w sposób ciągły". Dla lotniska EPGD - Gdańsk im. Lecha Wałęsy, w AIP Polska zapisano: „W odległości 15 metrów od punktu zatrzymania, wyświetla się dystans do przebycia poprzez wyłączenie kolejnych rzędów wskaźników LED. Na wyświetlaczu podana również zostaje wartość liczbowa (metry) przedstawiająca odległość do zatrzymania."

Dla lotniska EPWR - Wrocław - Strachowice czytamy, iż: „W odległości $30 \mathrm{~m}$ od miejsca zatrzymania wskaźnik stopnia zbliżania przedstawia pilotowi pozostały do przebycia dystans przez wyłączenie kolejnych rzędów wskaźników LED. Wyłączenie jednego rzędu oznacza przebycie $0,5 \mathrm{~m}$."

Dla lotniska EPWA - Chopina w Warszawie zapisy AIP Polska podają, iż: „W odległości 12 metrów od punktu zatrzymania, wyświetla się dystans do przebycia poprzez wyłączenie kolejnych rzędów wskaźników LED. Wyłączenie jednego rzędu oznacza przebycie 0,5 metra. Wyłączenie wszystkich rzędów LED oznacza odległość 0,5 metra do punktu zatrzymania”.

Informacje opublikowane w AIP Polska dla lotnisk w Gdańsku oraz Wrocławiu nie budzą wątpliwości Autorów, choć zapisy AIP Polska, dotyczące automatycznego 
systemu dokowania „Safegate”, nie wspominają nic o prędkości zbliżania, która, zgodnie z obowiązującymi wymaganiami, powinna być również zapewniana w sposób ciągły. Dla lotniska EPWA Chopina w Warszawie natomiast stwierdzono rozbieżność między wymaganiami (w skrócie: $15 \mathrm{~m}$ od miejsca zatrzymania), dotyczącymi systemu A-VDGS, opublikowanymi w Załączniku 14 ICAO [10], a informacjami opublikowanymi w AIP Polska (w skrócie: 12 metrów od punktu zatrzymania). W tej sytuacji Autorzy zadali sobie pytanie o możliwe przyczyny, źródła czy też miejsce i sposób materializacji stwierdzonej niezgodności. Zaś mając świadomość, iż błąd danych i informacji może wystąpić na każdym etapie łańcucha dostaw danych i informacji lotniczych [2], zarówno w fazach zamówienia, tworzenia, oceny i akceptacji, przygotowania, publikacji czy też wykorzystania końcowego danych i informacji lotniczych, a jego przyczyny, źródło czy też miejsce i sposób materializacji mogą być różne, wykorzystali opisany przypadek jako przykład uzasadniający cel i kierunek podjętych prac w dziedzinie zapewnienia jakości danych i informacji lotniczych.

\section{Analiza potencjalnej niezgodności}

Opisany powyżej przypadek Autorzy poddali tylko analizie teoretycznej, odstępując od przeprowadzenia analizy stanu faktycznego.

Stwierdzona rozbieżność informacji opublikowanych w AIP Polska z wymaganiami Załącznika 14 ICAO [10] może, ale nie musi być niezgodnością, jeżeli zostało formalnie zatwierdzone przedmiotowe odstępstwo - informacja o tym podlega obowiązkowi zgłoszenia do Rady ICAO i opublikowania w Załączniku 14 ICAO, jak również w AIP Polska.

Przyjmując $w$ dalszych rozważaniach, że w sensie formalnym analizowany przypadek jest niezgodnością, należy ustalić podstawową kwestię miejsca wystąpienia niezgodności - czy niezgodność dotyczy parametrów systemu A-VDGS, a opublikowane w AIP Polska informacje są poprawne?, albo czy parametry systemu A-VDGS nie spełniają wymagań Załącznika 14 ICAO, a opublikowane w AIP Polska informacje są poprawne? Sformułowanie tego zagadnienia implikuje istotne spostrzeżenie, o konieczności ustalenia faktycznego stanu i miejsca wystąpienia niezgodności, w przypadku stwierdzenia potencjalnej niezgodności danych i informacji lotniczych.

Przyjmując $\mathrm{w}$ dalszych rozważaniach, że w sensie faktycznym parametry systemu A-VDGS są zgodne z wymaganiami Załącznika 14 ICAO [10], należy poddać dalszej analizie łańcuch danych i informacji lotniczych (rysunek 4), będący przedmiotem wcześniejszych badań i publikacji Autorów [3,5], a w szczególności schemat tworzenia (rysunek 5) danych i informacji, zawierający tylko element kontroli końcowej, który jak należy założyć w rozpatrywanym przypadku, okazał się nieskuteczny lub został pominięty. 
Analysis of aeronautical information potential incompatibility - case study Analiza potencjalnej niezgodności informacji lotniczej-studium przypadku
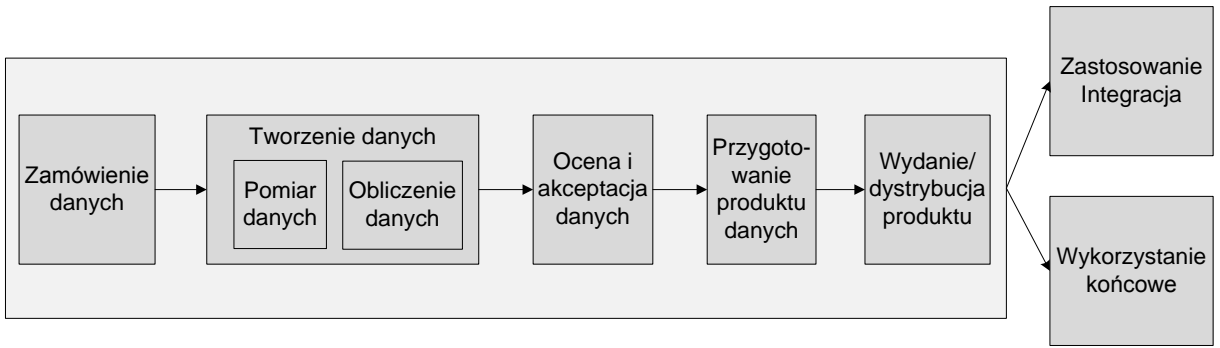

Rys. 4. Łańcuch danych lotniczych (na podstawie [8])

Prowadząc analizę przedmiotowej niezgodności zgodnie $\mathrm{z}$ formalnie obowiązującymi schematami tworzenia i publikacji (rysunek: 4, 5) danych i informacji lotniczych Autorzy zwracają szczególną uwagę na fakt, że przedmiotowa niezgodność została zidentyfikowana dopiero po publikacji w AIP Polska, a więc na etapie końcowego wykorzystania informacji lotniczych (rysunek 4). W takim stanie, analizę niezgodności, począwszy od ustalenie miejsca jej wystąpienia, a następnie przyczyn i określenia adekwatnych działań zapobiegawczych i korygujących, należy przeprowadzić metodą „pod prąd”, z zastrzeżeniem, że w skrajnym przypadku, wystąpienie niezgodności mogło mieć miejsce już na etapie zamówienia danych (rysunek 4) i udostępnienia danych źródłowych, np. dokumentacji producenta i/lub dostawcy systemu A-VDGS.

Analiza określonego schematu (rysunek 5) prowadzi do oczywistego stwierdzenia, że stosowanie go w praktyce uniemożliwia bieżącą identyfikację niezgodności, jak również utrudnia późniejsze ustalenia miejsca / etapu, w którym niezgodność wystąpiła (wynik „NIE” etapu 4). Analizując każdy etap, konieczne będzie ustalenie poprawności danych wejściowych, metody i wyniku przetworzenia (pomiaru, analizy, redakcji, edycji, formatowania), i końcowo danych wyjściowych, a ponadto weryfikacji zgodności danych na wyjściu i wejściu pomiędzy kolejnymi etapami. Uwzględniając datę publikacji, Autorzy zwracają uwagę na to, że $\mathrm{w}$ praktyce będzie to wiązało się $\mathrm{z}$ koniecznością pobierania danych i zapisów już zarchiwizowanych, co będzie skutkowało koniecznością czasochłonnego ustalania miejsca wystąpienia niezgodności i ewentualnego wprowadzenia ograniczeń operacyjnych, do czasu zakończenia analizy i zrealizowania działań korygujących i zapobiegawczych. Ale zaplanowanie tych działań będzie również czasochłonne, z uwagi na konieczność ustalenia przyczyn wystąpienia niezgodności, np. z zastosowaniem diagramu Ishikawy [7], a następnie określenia możliwych sposobów zapobieżenia powtórnemu wystąpieniu niezgodności i metod ograniczenia wielkości ich skutków [6].

W związku z tym Autorzy we wcześniejszej pracy [3] zaproponowali modyfikację schematu tworzenia danych lotniczych, polegającą na wprowadzeniu do każdego etapu weryfikacji i walidacji (rysunek 6), dzięki czemu potencjalna lub rzeczywista niezgodność zostanie zidentyfikowana na bieżąco, a zaplanowanie i realizacja działań zapobiegawczych i korygujących będzie zajmowała znacznie mniej czasu. 


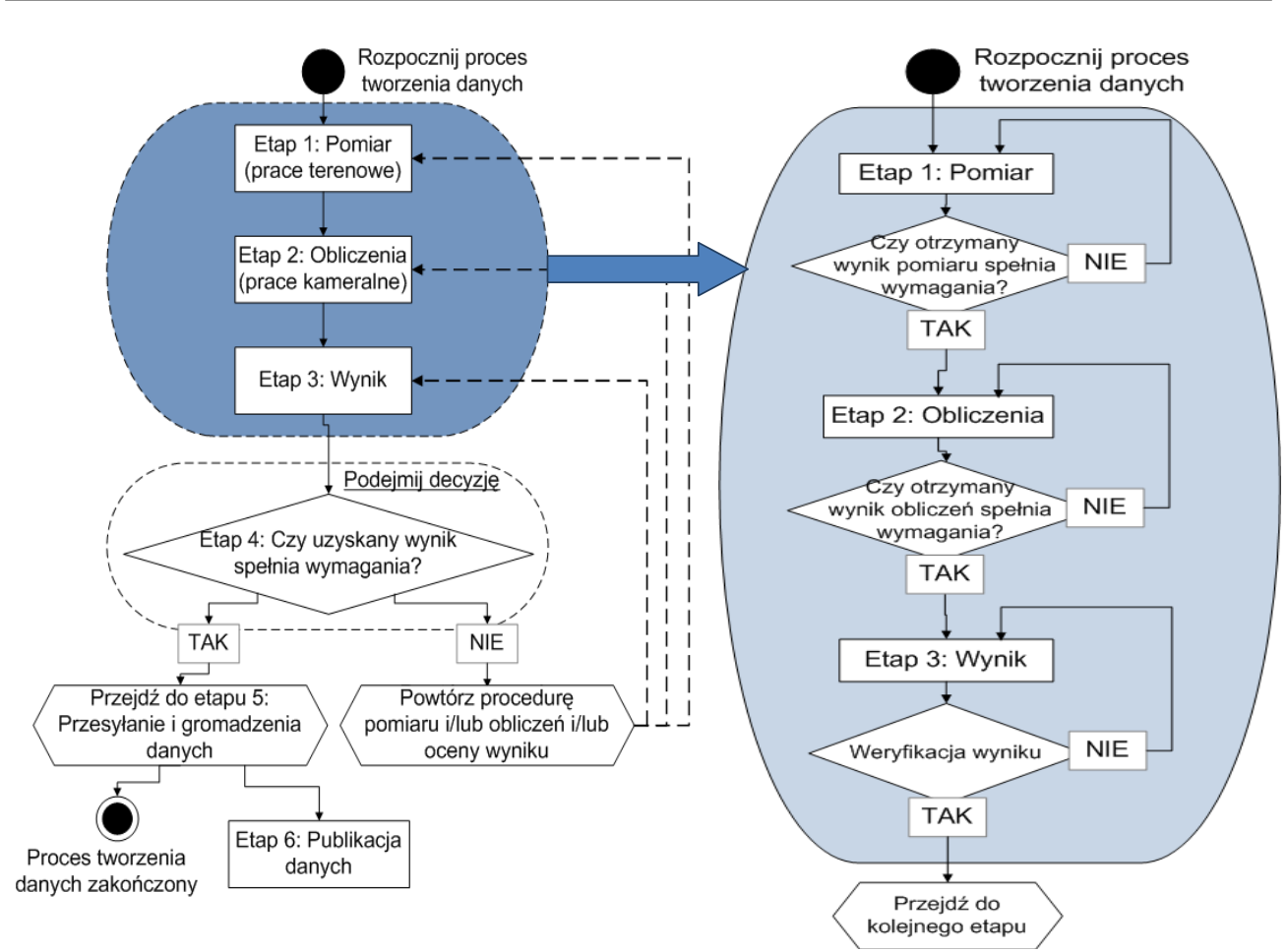
Rys. 5. Schemat pozyskania danych lotniczych z ocena końcowa [opracowanie wtasne]
Rys. 6. Schemat pozyskania danych lotniczych z ocenami etapowymi [opracowanie wtasne]

\section{Podsumowanie}

Transport lotniczy jest dziedziną bardzo silnie obwarowaną formalnie opublikowanymi specyfikacjami, wymaganiami, procedurami i przepisami, w celu zapewnienia najwyższego poziomu bezpieczeństwa operacji lotniczych. Również (zgodnie z tymi przepisami) działania podejmowane $\mathrm{w}$ ramach łańcucha danych i informacji lotniczych oraz podmioty w nich uczestniczące podlegają kontroli i certyfikacji. Pomimo tak rozbudowanego systemu nadzoru, licznych procedur weryfikacji oraz wprowadzeniu zabezpieczeń zdarza się, iż błędne dane lub informacje lotnicze zostają przekazane końcowym odbiorcom w osobach członków personelu lotniczego, a przyczyny, źródło czy też miejsce i sposób materializacji niezgodności są trudne do natychmiastowego ustalenia. Wynika to $\mathrm{w}$ dużej mierze $\mathrm{z}$ faktu, iż opublikowane wymagania, specyfikacje i algorytmy wprowadzaja jedynie obowiązek stosowania kontroli końcowej. Brak jest natomiast weryfikacji etapowej (zagadnienie to omówiono szerzej w innej pracy Autorów [3]) oraz algorytmów oceny i ewaluacji jakości danych i informacji lotniczychwe wszystkich fazach ich istnienia. Wskazany w niniejszym artykule przykładowy przypadek potencjalnej niezgodności w publikacji lotniczej potwierdza konieczność opracowania i wdrożenia kompleksowej metody zapewnienia jakości (oceny i kontroli, ewaluacji i walidacji) danych i informacji lotniczych na wszystkich etapach łańcucha danych lotniczych, co jest przedmiotem dalszych prac Autorów i uzasadnia wcześniej sformułowane tezy dotyczące celu i kierunku koniecznych przedsięwzięć. 
Analysis of aeronautical information potential incompatibility - case study Analiza potencjalnej niezgodności informacji lotniczej-studium przypadku

\section{Literatura}

[1] Dudek E., Kozłowski M.: Koncepcja procesu oceny jakości danych lotniczych, Prace Naukowe Politechniki Warszawskiej - Transport, z. 113, str. 131-140, Warszawa 2016, nr ISSN: 1230-9265.

[2] Dudek E., Kozłowski M.: Koncepcja zarządzania jakością danych lotniczych, Prace Naukowe Politechniki Warszawskiej - Transport, z. 113, str. 141-150, Warszawa 2016, nr ISSN: 1230-9265.

[3] Dudek E., Kozłowski M.: Koncepcja zastosowania metodyki DMAIC do zapewnienia jakości danych lotniczych, [w] Kwasiborska A. (red.): Transport lotniczy i jego otoczenie, Wydział Transportu Politechniki Warszawskiej, str. 67-78, Warszawa 2016, nr ISBN: 978-83-7814-548-6.

[4] Dudek E., Kozłowski M.: The concept of a method ensuring aeronautical data quality, Journal of KONBiN No 1(37)2016, str. 319-340, Warszawa 2016, nr ISSN: 1895-8281.

[5] Kozłowski M., Dudek E.: NOTAM jako bariera bezpieczeństwa informacji lotniczych, artykuł złożony do druku w ramach VI Międzynarodowej Konferencji Naukowej Bezpieczeństwo w portach lotniczych i morskich, Dęblin, wrzesień 2016.

[6] Kozłowski M., Malarski M.: Metody badania przyczyn i skutków zagrożenia bezpieczeństwa ruchu lotniskowego, XXXIII ZSN, Szczyrk 2005 r.

[7] Kozłowski M., Winiewski A.: Diagram Ishikawy w systemie zarządzania bezpieczeństwem w porcie lotniczym, XXXIV ZSN, Szczyrk 2006 r.

[8] Specyfikacja Eurocontrol - Poziomy ufności danych, $\mathrm{nr}$ referencyjny dokumentu: EUROCONTROL-SPEC-0148.

[9] www.ais.pata.pl/aip (data dostępu 8.11.2016 roku).

[10] Załącznik 14 do Konwencji o międzynarodowym lotnictwie cywilnym, Lotniska, Organizacja Międzynarodowego Lotnictwa Cywilnego, lipiec 2009.

[11] Załącznik 15 do Konwencji o międzynarodowym lotnictwie cywilnym, Służby Informacji Lotniczej, Organizacja Międzynarodowego Lotnictwa Cywilnego, lipiec 2013.

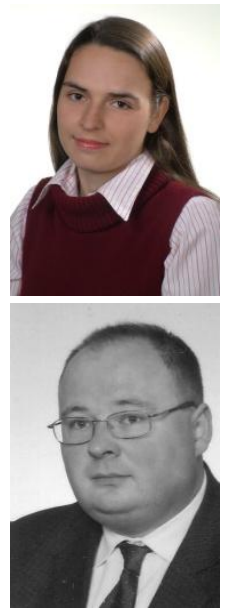

mgr inz. Ewa Dudek pracuje na stanowisku asystenta w Zakładzie Telekomunikacji $w$ Transporcie na Wydziale Transportu Politechniki Warszawskiej. Zainteresowania naukowe obejmuja telematyke transportu, integrację systemów, zagadnienia, zwiazane $z$ ruchem lotniczym oraz automatyke procesów ciaglych (udzial $50 \%)$.

Michat Kozlowski - Adiunkt $w$ Zakładzie Inżynierii Transportu Lotniczego Wydziatu Transportu Politechniki Warszawskiej. Bogate doświadczenie $w$ zakresie zarzadzania portem lotniczym, wyniesione z ponad dwudziestoletniej pracy zawodowej $w$ obszarze operacyjnym Lotniska Chopina $w$ Warszawie. Autor licznych badań, publikacji i wdrożeń, m.in. z zakresu systemów zarzadzania, w tym bezpieczeństwem i przepustowościa (udział 50\%). 